\title{
Sustainable alternative for the food industry: converting whey and orange juice into a micro-filtered beverage
}

\author{
Rafael Fagnani* ${ }^{\star}$ Ana Amélia Nunes Puppio, Emely Osti Zanon
}

Unopar University, Master of Dairy Science and Technology Degree Program, R. Marselha, 591 - 86041-140 - Londrina, PR - Brazil.

*Corresponding author <rafaelfagnani@hotmail.com>

Edited by: Luís Guilherme de Lima Ferreira Guido

Received September 06, 2016

Accepted January 03, 2017
ABSTRACT: Enhancing industrial sustainability by converting whey into alternative high valueadded products is a scientific trend in food science and technology. However, without other ingredients, rennet, or sour, whey has an unappetizing flavor. This sensory challenge can be overcome by blending it with citrus flavor from orange juice. This study assessed a micro-filtered beverage from whey and orange juice without enzymatic treatment. Four formulations (27:10, 8.6:10, 2.4:10 and 1:10 $\mathrm{v} / \mathrm{v}$ whey:juice ratio) were processed through a $1.4 \mu \mathrm{m}$ microfiltration system with four different transmembrane pressures $(1,2,3$, and 4.15 bar) and then stored at $5{ }^{\circ} \mathrm{C}$ for 28 days. The micro-filtered beverage was analyzed for physicochemical, sensorial and microbial changes. It was possible overcome the technological challenges of orange juice microfiltration without enzymatic treatment with high transmembrane pressures. The whey:orange juice ratio was also decisive for permeation. A clear beverage with lower viscosity, turbidity, and protein levels was obtained, without altering mineral concentrations thus showing that the product has good capacity for hydration. The beverage presented good microbiological quality and remained stable for 28 days at $5^{\circ} \mathrm{C}$. Sensory evaluation data indicate that the beverage can be directed to young people and women, regardless of their physical activity. The combination of whey and orange juice can be explored industrially as a micro-filtered beverage, with satisfactory results of physicochemical, microbiological and sensory acceptance.

Keywords: membrane, dairy, fruit, fouling, sensory evaluation

\section{Introduction}

Whey is considered a by-product of cheese production, with high pollution potential, due to the large amount of oxygen consumed during degradation. Unfortunately, only half of the whey produced is converted into high value-added products, such as protein isolates and dietary supplements (Yadav et al., 2015).

Currently, although the technological processes allow the production of whey powder protein isolates, bio-ethanol, biopolymers, electricity, single cell protein and various other proteinaceous products, these processes require considerable investments. Alternatively, membrane technology, such as microfiltration (MF) may be used, since manufacturing costs are lower and the products are well accepted (Gerardo et al., 2013).

Current research on sports nutrition has shown that whey proteins have a simultaneous capacity to hydrate and regenerate muscles after physical activity (Pegoretti et al., 2015). These data show a potential to develop refreshing whey-based beverages. However, whey alone can be unattractive because of its flavor. This sensory challenge can be overcome by blending whey flavor with citrus flavor from orange juice, especially in tropical regions.

Orange juice is widely accepted in many countries and is considered one of the main commodities in the global market. According to the Food and Agriculture Organization, world production of orange juice reached 71 million tons in 2014, accounting for more than $8 \%$ of the total production of fruit juice (FAO, 2015).
The main industrial limitation for MF is fouling. Aggregates of whey proteins and polysaccharides from orange, such as lignin, cellulose, and pectin may cause permeate flux decline (Nourbakhsh et al., 2014). While most academic studies have focused on enzymatic treatments to improve filterability of fruit juices, this research followed the trend of minimally processed foods, excluding the enzymatic treatment of orange juice in order to minimize industrial costs.

Considering the advantages of whey, such as low cost, capacity to hydrate and regeneration of muscles and the advantages of orange juice, such as great acceptability and refreshing flavor, this study aimed to produce a micro-filtered beverage containing these ingredients and evaluate the transmembrane flow, physicochemical characteristics, reduction of microbial load, shelf life and sensory acceptance.

\section{Materials and Methods}

\section{Raw materials}

To produce the beverage, sweet whey powder and orange juice concentrate with 66 Brix and 42.5 $\mathrm{g} \mathrm{dL}^{-1}$ sugar were used. The whey powder was rehydrated to obtain $6.5 \mathrm{~g} \mathrm{dL}^{-1}$ solid content. Orange juice was filtered through a 600 micron stainless steel filter prior to addition to the formulation to prevent fouling. The juice:whey ratios (v:v) were $27: 10 ; 8.6: 10 ; 2.4: 10$; and $1: 10$, parameters based on the juice manufacturer recommendations and on our previous sensory assessments. 


\section{Equipment}

Experiments were conducted using a microfiltration pilot skid system designed for batch or continuous pilot plant use. The system has a $50 \mathrm{~L}$ stainless steel feed tank and was equipped with a $1.4 \mu \mathrm{m}$ GP multi-channel ceramic (aluminum oxide) membrane with 19 channels, $4 \mathrm{~mm}$ channel diameter, $0.24 \mathrm{~m}^{2}$ filtration area and $1.020 \mathrm{~m}$ long.

The unit was equipped with gauges to monitor pressures at the feed inlet (P1), retentate outlet (P2), and the permeate (P3). The feed temperature was monitored at the pump. Transmembrane pressure (TMP) was calculated from the following equation

$\mathrm{TMP}=[(\mathrm{P} 1+\mathrm{P} 2) / 2]-\mathrm{P} 3$

Prior to the experiments, the microfiltration system was sanitized with 200 ppm sodium hypochlorite solution at $20^{\circ} \mathrm{C}$ for $20 \mathrm{~min}$ to reduce microorganisms. After each sanitization, the solution was rinsed out with demineralized water until the $\mathrm{pH}$ of the retentate and permeate streams equaled the $\mathrm{pH}$ of demineralized water.

After rinsing, the water flux and membrane resistance were determined using demineralized water. At the start of the beverage microfiltration, the remaining water was flushed out of the pipes with the feed. The volume concentration factor was calculated by the ratio of the initial feed mass to the retentate mass. The rejection factor for all solutes (proteins, fat, total solids, and ash) was calculated by the formula:

$\mathrm{R}=1$ - Cperm/Cfeed

where: $\mathrm{R}$ is rejection factor, Cperm is permeate concentration and $C f e e d$ is feed concentration.

\section{Manufacturing process}

The procedure was performed in $20 \mathrm{~L}$ batches. The beverage was formulated directly into the previously sanitized MF feed tank. The transmembrane pressures were 1,2, 3, and 4.15 bar (minimum and maximum pressures allowed by equipment limits).

The beverage permeation started when the temperature reached $50{ }^{\circ} \mathrm{C}\left( \pm 2{ }^{\circ} \mathrm{C}\right)$ with retentate recirculation. Temperature was based on manufacturer recommendations (minimum value for optimal solubilization conditions for juice and whey powder). Permeate flow and temperatures were measured every $1 \mathrm{~min}$ throughout the microfiltration process. All micro-filtered beverage was placed in a previously sanitized $50 \mathrm{~L}$ stainless steel tank (Figure 1). After the process, aliquots were collected directly from the permeate tank for physicochemical and microbiological analyses and stored at $5{ }^{\circ} \mathrm{C}$. The experiment was performed five times to account for randomized effects.

\section{Physicochemical analyses}

The $\mathrm{pH}$ was determined by a potentiometer by introducing the electrode directly into the sample. The $\mathrm{N}$ content was estimated by the micro-Kjeldahl method

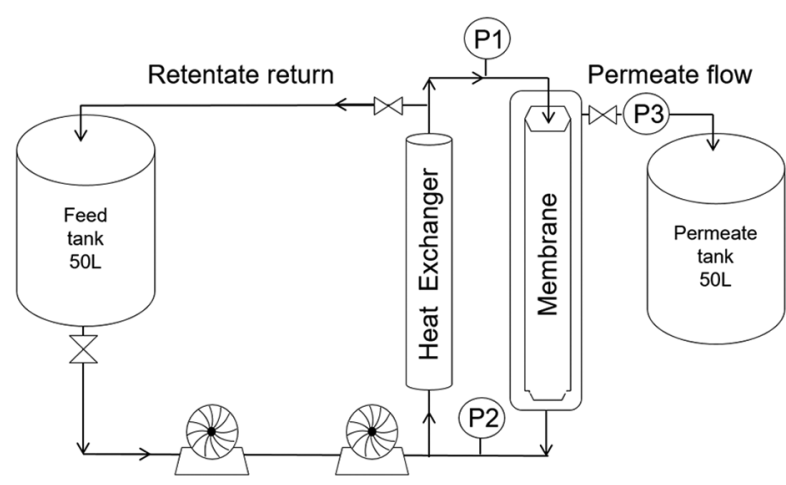

Figure 1 - Diagram of the pilot-scale microfiltration with pressure gauges (P1, P2 and P3).

followed by conversion $(\times 6.38)$ to crude protein $(\mathrm{CP})$ content expression (APHA, 2004). The Gerber's method was used to estimate fat content (APHA, 2004). Total solids (TS) were measured by oven drying at $105{ }^{\circ} \mathrm{C} / 16 \mathrm{~h}$ (APHA, 2004). Ash was determined according to APHA (2004) at $550{ }^{\circ} \mathrm{C} / 12 \mathrm{~h}$.

The viscosity was determined at $5{ }^{\circ} \mathrm{C}$ in the feed, micro-filtered beverage (permeate) and retentate, in triplicate. The samples were placed in $500 \mathrm{~mL}$ beakers and analyzed in a digital viscometer $(46 \mathrm{~mm}$ diameter disc spindle and $600 \mathrm{rpm}$ for $40 \mathrm{~s}$ ).

The absorbance (absorbance units, A.U.) and transmittance (percentage) were measured in triplicate in the feed, permeate and retentate. The samples were placed in crystal cuvettes and analyzed by spectrophotometry at $500 \mathrm{~nm}$ at $25^{\circ} \mathrm{C}\left( \pm 2{ }^{\circ} \mathrm{C}\right)$.

\section{Microbiological analyses}

The microbiological analyses were performed in the orange juice concentrate, reconstituted whey powder, feed and permeate, immediately after production and during 28 days of refrigerated storage $\left(5^{\circ} \mathrm{C}\right)$.

Aerobic mesophilic microorganisms were counted by pour plating on PCA (Plate Count Agar) incubated at $37^{\circ} \mathrm{C} / 48 \mathrm{~h}$ in duplicate (APHA, 2004). Total coliforms and $E$. coli were counted by sample incubation on $3 \mathrm{M}^{\mathrm{TM}}$ Petrifilm EC plates at $37^{\circ} \mathrm{C} / 24 \mathrm{~h}$ and $37^{\circ} \mathrm{C} / 48 \mathrm{~h}$, respectively. Yeast and mold were counted by incubation of the sample on $3 \mathrm{M}^{\mathrm{TM}}$ Petrifilm YM plates at $25{ }^{\circ} \mathrm{C}$ for 5 days. All dilutions were made in peptone sterile water $0.1 \mathrm{~g} \mathrm{dL}^{-1}$.

To evaluate the effect of MF on the reduction of the initial microbial load, five aliquots of $300 \mathrm{~mL}$ of the micro-filtered beverage were collected directly from the permeate tank with a sterile pipette and stored in sterile plastic bags at $5{ }^{\circ} \mathrm{C}$. The samples were evaluated on the day of processing and every $7 \mathrm{~d}$ after production (days 7 , 14,21 and 28).

\section{Sensory evaluation}

The sensory acceptance test of the micro-filtered beverage was performed with participants from Lon- 
drina, Paraná State, Brazil, regardless of gender, age or occupation. The sensory evaluation was planned for 100 people according to Lawless and Heymann (2010), who suggest between 70 and 100 participants for acceptance tests. The evaluation was made by 87 participants. The sensory analysis was performed in individual booths, and $150 \mathrm{~mL}$ beverage at $5^{\circ} \mathrm{C}$ were presented in transparent disposable cups $(180 \mathrm{~mL})$ on a white surface. The presentation was accompanied by an evaluation form, salty biscuits and drinking water to cleanse the palate between samples.

The overall impression and the attributes flavor and aroma were evaluated using a structured ninepoint hedonic scale, ranging from 1 (disliked extremely) to 9 (liked very much). The acceptability index (AI) was calculated according to the following equation:

$\mathrm{AI}(\%)=\mathrm{A} \times 100 / \mathrm{B}$

where: $\mathrm{A}$ = average score obtained for the product, and $\mathrm{B}=$ maximum score given to the product. $\mathrm{AI} \geq 70 \%$ is considered a good response (Ferreira, 2000).

Similar evaluation was performed for the purchase intention, using a 5-point structured scale ranging from 1 (I would definitely buy) to 5 (I would definitely not buy).

The attributes color, sweetness, and acidity were evaluated by specific acceptance tests, with nine verbal scales structured according to the intensity levels. A verbal scale was used to cover the extreme range (9-extremely strong or 1-extremely weak), and the ideal (5-color sweetness or acidity in the right amount). The sensory evaluation was performed after approval by the UNOPAR Research Ethics Committee (approval number 1.148.288).

\section{Statistical analysis}

The effect of MF on viscosity, $\mathrm{pH}$, protein level, beverage absorbance and transmittance was evaluated in the experimental design. The effect of MF and storage time $\left(7,14,21\right.$ and 28 days at $\left.5^{\circ} \mathrm{C}\right)$ on mesophilic aerobic counts, molds, yeast, coliforms at $35^{\circ} \mathrm{C}$, and $E$. coli were also assessed. Counts below the detection limit were regarded as the lowest number of a decimal unit. Thus, the absence of microbial growth was regarded as $0.9 \mathrm{CFU}$ $\mathrm{mL}^{-1}$ to allow the descriptive statistical analysis.

The absence of normality and homoscedasticity were observed by the Kolmogorov-Smirnov test and the Liliefors test for all variables $(p<0.05)$. Thus, differences before and after the MF process were evaluated using the paired Wilcoxon test at $p<0.05$.

The participants were classified by gender (male or female), physical activity (yes or no) and age (up to 20 years old or more than 20 years old). The experimental design pondered differences of overall impression, aroma, flavor, color, sweetness, acidity and purchase intent between categories of gender, physical activity and age. The Mann-Whitney test was used with 0.05 significance level. The Statistica 7.0 program (Statsoft) was used for all analyses.

\section{Results and Discussion}

\section{Manufacturing process}

The most important combination of parameters that affected microfiltration performance was transmembrane pressure and whey/orange juice ratio. Among all the formulations and pressure conditions, only the combination of 4.15 bar transmembrane pressure 15.2 bar inlet pressure and 3.1 bar outlet pressure) and 1: 10 juice:whey ratio allowed the permeate flow.

Under these conditions, microfiltration batches (20 L) lasted $5.8 \mathrm{~min}$, with $242.2 \mathrm{~L} \mathrm{~h}^{-1} \mathrm{~m}^{-2}$ initial permeation flux and $173.6 \mathrm{~L} \mathrm{~h}^{-1} \mathrm{~m}^{-2}$ final flux. The volumetric concentration factor $(\mathrm{VCF})$ was 2.09 , considering the initial volume of $19.615 \mathrm{~kg}$ beverage and $10.253 \mathrm{~kg}$ permeate. The rejection factor for protein, fat, total solids, and ash is given in Figure 2.

The process was carried out in a short time 15.8 min), without evidencing steady flow permeation. Thus, the mechanisms of particle deposition were not evaluated. However, it was observed that the permeate flux decreased more than $28 \%$ throughout the process $\mid<$ $6 \mathrm{~min})$.

This abrupt flux decrease is common in whey and fruit juice microfiltration, probably due to components in the juice and whey. However, flow resistance depends on different fouling mechanisms. In relation to the juice concentrate, larger molecules such as pectin, hemicellulose, and lignin may deposit and adhere to the membrane surface (gel layer) (Razi et al., 2012), which is also favored when the particle size is larger than the membrane pores.

For whey molecular composition, flow resistance may be attributed to fouling within the pores, since molecules smaller than the membrane pores $(1.4 \mathrm{~mm})$ predominate, such as soluble proteins and minerals. $\beta$-lactoglobulin ( $\beta$-LG) contributes to the formation of deposits due to its tendency to associate with $\mathrm{Ca}$ and $\mathrm{K}$, forming dimers (Mourouzidis-Mourouzis and Karabelas, 2006). In addition, $\alpha$-lactalbumin ( $\alpha$-LA) has the ability to bind strongly to $\mathrm{Ca}^{+2}$, forming inorganic salt deposits, thus leading to pore blockage. Among the minerals, calcium phosphate is considered one of the main causes of membrane fouling and flux/flow decline, which may form deposits on the membrane surface and inside the pores (Rice et al., 2009; Tan et al., 2014).

The operating conditions can also determine fouling. Some authors have reported that high transmembrane pressures (> 1 bar) and larger pore diameters (> $0.8 \mu \mathrm{m})$, similar to the conditions used in this study, can favor fouling due to complete pore blockage /Oliveira et al., 2010; Todisco et al., 1996).

As the beverage of this study was not subjected to enzymatic reactions, there was no reduction for macromolecules from the orange juice concentrate. Thus, the fouling mechanism most probably occurred due to cake formation, since the molecule size plays a key role in molecule accumulation on the membrane surface (Domingues et al., 2014). 

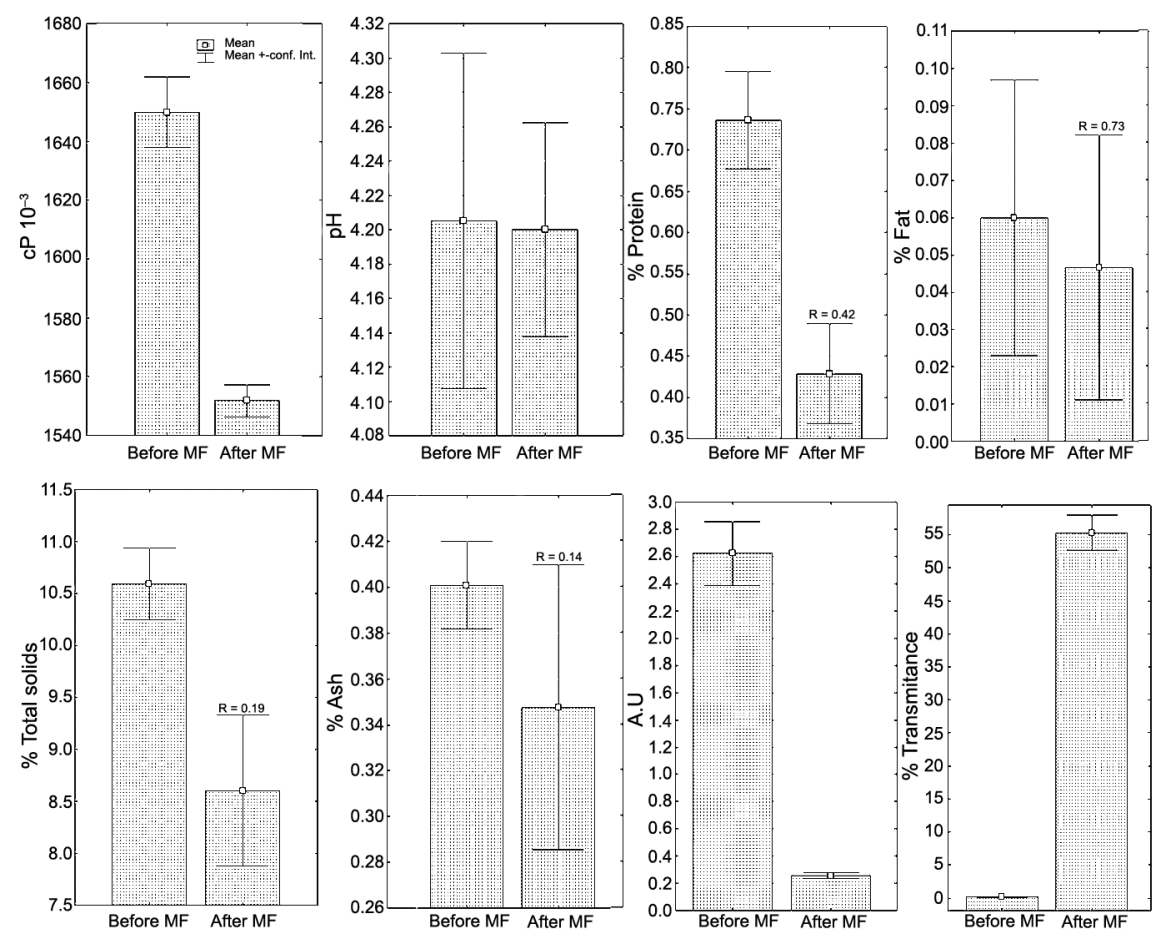

Figure 2 - Mean and confidence interval (95\% Ci) of viscosity, pH, protein percentage, fat, total solids (TS), ash, absorbance and transmittance before and after beverage microfiltration and rejection factor (R) for protein, fat, total solids and ash.

The high pressures used in this experiment may have also contributed to the formation of a fouling layer on the membrane surface. According to Mirsaeedghazi et al. (2009) and Razi et al. (2012), fouling correlates positively with the increase in transmembrane pressure and temperature by increasing the macromolecule diffusion coefficient and favoring penetration and deposition in the membrane pores (Wang et al., 2012).

\section{Physicochemical analyses}

The permeate exhibited lower $(p<0.05)$ viscosity and turbidity when compared to the feed, resulting in a clear product, with greater light penetration (Figure 2). This result is due to the retention of macromolecules suspended by the MF membrane (Gaschi et al., 2014). In the case of beverages containing orange juice, carotenoids are the main components responsible for the characteristic color, which can be retained in the filtration process not only because of molecule size, but also due to the interaction between liposoluble substances and the membrane material (Cisse et al., 2005).

In this study, proteins were the main components retained by the membrane, with initial concentrations of $0.74 \pm 0.11 \mathrm{~g} \mathrm{dL}^{-1}$, which decreased to $0.43 \pm 0.11 \mathrm{~g}$ $\mathrm{dL}^{-1}$ in the permeate beverage $(p<0.05)$. Consequently, lower $(p<0.05)$ TS values were also observed, which decreased from $10.59 \mathrm{~g} \mathrm{dL}^{-1} \pm 0.63$ to $8.62 \mathrm{~g} \mathrm{dL}^{-1} \pm 1.33$ in the permeate (Figure 2). The membrane pores are not able to retain whey proteins, since soluble protein diam- eters range from 3 to $6 \mathrm{~nm}$, which are smaller than the membrane pores (1.4 $\mu \mathrm{m})$ (Garcia et al., 2013). However, pore blockage, caused primarily by interactions between pectin and minerals from whey, may change the original membrane permeability, leading to soluble protein retention (Li et al., 2012).

Some authors have reported different behavior when the membrane permeates only whey. Mourouzidis-Mourouzis and Karabelas (2006) found protein transmission greater than $96 \%$, which corroborates the studies by Tracey and Davis (1994) using conventional MF, and Guell and Davis (1996) in a tangential MF process, who found protein retention lower than $15 \%$. These data show that the interaction between the macromolecules from orange juice and whey components can lead to an unexpected retention of soluble proteins.

The protein rejection by the membrane was a curious surprise for us. We were expecting some rejection, but not as high as observed in this study. To avoid this kind of rejection, we could adjust some parameters, such as transmembrane pressure, tangential flow and others. Nevertheless, the absence of enzymatic treatment restricted all possibilities, since among all the combinations of formulations and pressures, only the 1: 10 juice: whey ratio with 4.15 bar transmembrane pressure allowed the permeate flow.

Regarding the physicochemical analyses, no significant differences were observed for $\mathrm{pH}$, fat, and ash $(p>0.05)$ between the feed and permeate (Figure 2). 
The membrane technology can remove over $98 \%$ of the original lipids (Michalski et al., 2006). However, in this experiment, the feed had lower fat levels $10.17 \pm 0.07 \mathrm{~g}$ $\mathrm{dL}^{-1}$, which may have been responsible for the lack of statistical difference when compared to levels obtained for the permeate $\left(0.05 \pm 0.06 \mathrm{~g} \mathrm{dL}^{-1}\right)$.

With respect to ash content, it is confirmed that the membrane allows passage of most minerals, allowing the permeate to keep salt concentration, which is considered positive due to the original mineral content of whey and juice. Several studies have reported the hydration potential of these foods, associating the mineral levels to better water absorption in the intestinal tract (Solak and Akin, 2012). This result shows that the product can be used for rehydration after physical activity.

Watson et al. (2008) compared the hydration capacity of commercial isotonic drink and skimmed milk, and found no changes when the isotonic drink was replaced by milk, proving the efficiency of skimmed milk in hydration. Other authors have shown the effect of $\beta$-lactalbumin on hydration, with improvement in the intestinal function (Wernimont et al., 2015). These results provide information on the potential of sports beverages to hydrate individuals after exercise, although more studies are required to confirm this hypothesis.

The retentate had the lowest transmittance and highest absorbance when compared to the permeate, with values outside the spectrophotometer detection limit ( $<0.1$ or $>9999.9$ A.U. or percentage) in all replications $(p<0.05)$. These data indicate higher molecule concentration, shown by the protein levels, which was higher $(p<0.05)$ in the retentate as compared to the permeate, with average values of $1.13 \mathrm{~g} \mathrm{dL}^{-1} \pm 0.16$, confirming the retention of protein and other compounds that reduce TS in the permeate, concentrating the solids in the retentate.

Thus, the mean values for total solids in the retentate was $18.87 \mathrm{~g} \mathrm{dL}^{-1} \pm 1.27$, with $0.73 \mathrm{~g} \mathrm{dL}^{-1} \pm 0.15$ ash, $0.1 \mathrm{~g} \mathrm{dL}^{-1} \pm 0.04$ fat, $1676.04 \mathrm{cP} .10^{-3} \pm 18.02$ for viscosity and $4.20 \pm 0.06$ for $\mathrm{pH}$. As discussed above, microfiltration retained most of the suspended solids in the retentate, including protein.

\section{Microbial counts}

The microbial counts of raw materials were performed before beverage formulation, and the values

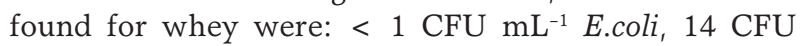

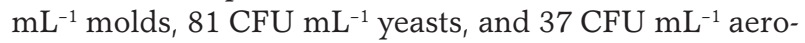
bic mesophilic microorganisms. The counts in the or-

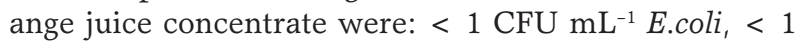

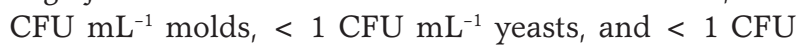
$\mathrm{mL}^{-1}$ aerobic mesophilic bacteria.

The microorganism counts in the feed before MF and in the permeate are shown in Table 1. MF was able to reduce $3.71 \mathrm{log}$ cycles in aerobic mesophilic counts. Lower counts were observed for coliforms at $35^{\circ} \mathrm{C}$ and yeasts (Table 1), which shows the efficiency of microfiltration to remove microorganisms with cell size between 0.4 to $2.0 \mu \mathrm{m}$ (Brans, 2004).
Table 1 - Median, mean and standard deviation (SD) of aerobic mesophilic microorganisms, yeasts, molds, coliforms at $35^{\circ} \mathrm{C}$ and Escherichia coli counts before and after beverage microfiltration.

\begin{tabular}{lcrc}
\hline & & Median & Mean \pm SD \\
\hline $\begin{array}{l}\text { Aerobic mesophilic } \\
\text { (log CFU mL }\end{array}$ & Before & $5.75^{\mathrm{a}}$ & $5.57 \pm 2.85$ \\
\hline Mold & After & $1.79^{\mathrm{b}}$ & $1.86 \pm 0.58$ \\
\hline (CFU mL & Before & $1.00^{\mathrm{a}}$ & $5.36 \pm 6.06$ \\
\hline Yeast & After & $0.90^{\mathrm{a}}$ & $1.34 \pm 0.60$ \\
(CFU mL $\mathrm{mL}^{-1}$ ) & Before & $15.00^{\mathrm{a}}$ & $17.20 \pm 7.09$ \\
\hline Colif. $35^{\circ} \mathrm{C}$ & After & $<1.00^{\mathrm{b}}$ & $<1 \pm 0.00$ \\
\hline (CFU mL & Before & $301.00^{\mathrm{a}}$ & $349.80 \pm 288.56$ \\
\hline E.coli & After & $4.00^{\mathrm{b}}$ & $4.63 \pm 4.09$ \\
(CFU mL & Before & $<1.00^{\mathrm{a}}$ & $<1.00 \pm 0.00$ \\
\hline
\end{tabular}

abMedians followed by different lowercase letters in columns differ by the Wilcoxon test $(p<0.05)$.

Several authors have found total bacterial reductions within the range of 4-5 $\log \mathrm{CFU} \mathrm{mL}^{-1}$, which are directly related to initial contamination levels, operating parameters, and membrane characteristics (Antunes et al., 2014; Rezzadori et al., 2014). The results of this experiment are consistent with results in many studies, since lower counts were observed for mesophilic aerobic bacteria and yeasts, which were higher in numbers before MF (Table 1).

Regarding the molds and E. coli, significant reductions were observed $(p>0.05)$, since these counts were already low before the MF process, averaging 5.36 CFU $\mathrm{mL}^{-1}$ for molds, and E. coli was not detected (Table 1).

In Brazilian regulations, there are no standardized microbiological counts for beverages containing whey and fruit juice. Similar beverages can be found in the regulation of the National Health Surveillance Agency (ANVISA), such as milk beverages and juices containing fruit pulp. In these products, the Brazilian law, in line with the Codex Alimentarius, allows a maximum of $10 \mathrm{CFU} \mathrm{mL}^{-1}$ coliforms at $45^{\circ} \mathrm{C}$ for milk beverages, and $100 \mathrm{CFU} \mathrm{mL}^{-1}$ for fruit juices. Thus, all batches of beverage produced in this study complied with statutory regulation in Brazil for coliforms at $45^{\circ} \mathrm{C}$ (ANVISA, 2001).

Regarding microorganism growth, the aerobic mesophilic population tended to decrease during storage due to the microbiological barriers conferred by $\mathrm{pH}(4.20 \pm$ $0.10)$ and temperature $\left(5^{\circ} \mathrm{C}\right)$. Figure 3 shows that peak values of $1.79 \log \mathrm{CFU} \mathrm{mL} \mathrm{m}^{-1}$ were observed for mesophilic counts immediately after the MF process. The most significant decreases $(p<0.05)$ were observed after 7 and $21 \mathrm{~d}$ of storage, reaching mean values of 1.22 and $0.90 \mathrm{log}$ CFU $\mathrm{mL}^{-1}$, respectively.

No significant $(p>0.05)$ differences were observed for $\mathrm{pH}$ and molds yeast and coliform counts at $35^{\circ} \mathrm{C}$ and E.coli during $28 \mathrm{~d}$ of refrigerated storage $\left(5^{\circ} \mathrm{C}\right)$. Considering the beverage $\mathrm{pH}(4.20 \pm 0.10)$ and the storage temperature, molds and yeasts are the main spoiling microorganisms. However, the number of such microorganisms remained constant during $28 \mathrm{~d}$ of refrigerated storage due to the low initial counts in the permeate. 


\section{Sensory evaluation}

The characteristics of the participants are shown in Figure 4. There was homogeneity of the population in relation to gender, physical activity and age, with $43 \%$ males and $57 \%$ females, of which $52 \%$ practice physical activity and $48 \%$ do not exercise, and the average age was 40 years (18-62 years). The physical activity frequency was $13 \%$ for once a week, $9 \%$ up to twice a week, $25 \%$ up to three times a week, $18 \%$ up to four times a week, $13 \%$ up to five times a week, and $16 \%$ exercised daily.

The acceptability index (AI) for the overall impression of the beverage was $70 \%$, with $78 \%$ of scores above the classification "like slightly" (Figure 5). The good acceptance of a product is shown by response frequency "liked very much" and "liked" greater than $70 \%$ (Ferreira, 2000). Therefore, the beverage of the present study was well accepted by the participants. The acceptability levels for aroma and flavor were $64 \%$ and $66 \%$, respectively, showing that improvements could still be made to these attributes.

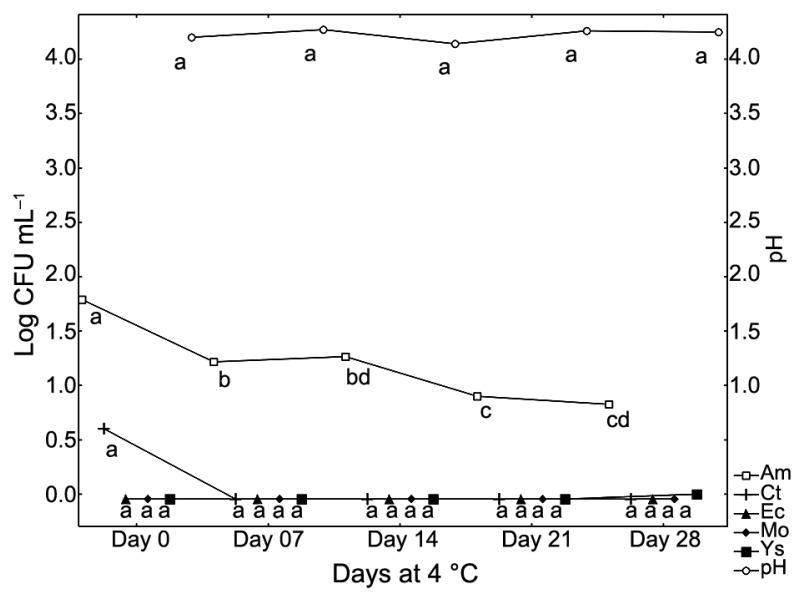

Figure 3 - Oscillation count of $\mathrm{pH}$, aerobic mesophilic microorganisms (Am), Mold (Mo), yeast (Ys), coliform at $35{ }^{\circ} \mathrm{C}$ (Ct) and Escherichia coli (EC) count (Log CFU) of micro-filtered beverage made from whey and orange juice stored at $4{ }^{\circ} \mathrm{C}$ during shelf life time.

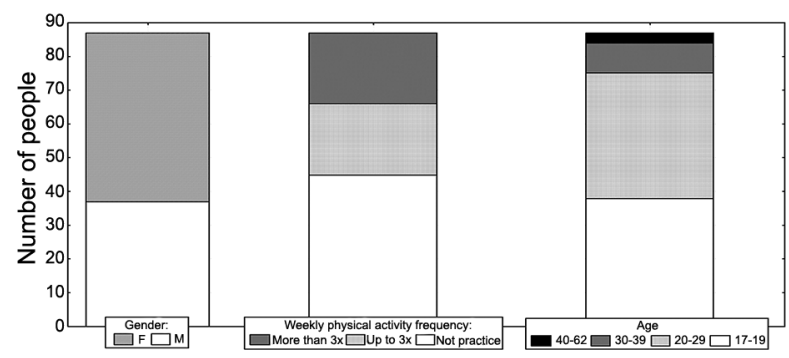

Figure 4 - Absolute frequency of 87 participants grouped according to gender, physical activity frequency and age.

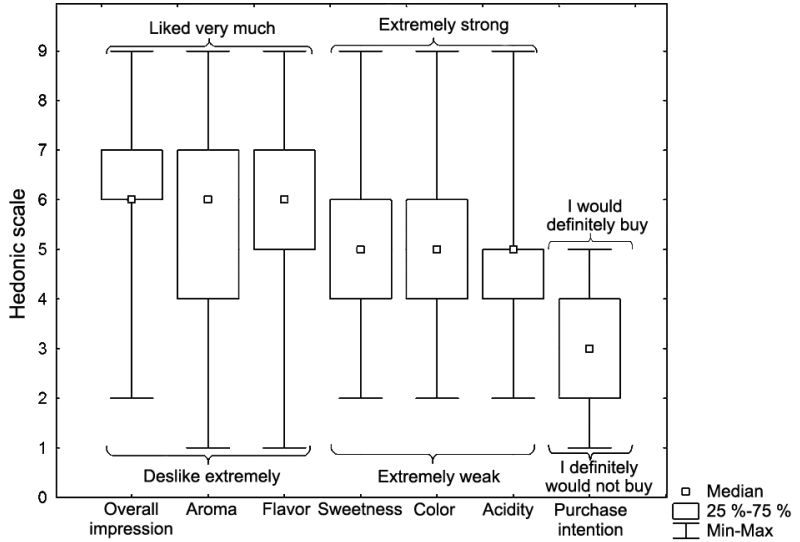

Figure 5 - Median, quartiles (25 \% - $75 \%$ ) and range (min-max) of sensory evaluation scores for overall impression, aroma, flavor, color, sweetness, acidity and purchase intention of microfiltered beverage from whey and orange juice performed with 87 participants.

MF is responsible for retaining volatile compounds, which give the typical aroma to orange juice. Open conditions during processing, as occurred in this experiment, may lead to aroma losses due to direct contact with atmospheric air (Rezzadori et al., 2014). Unlike a pilot plant, actual industrial conditions allow MF to occur in closed pipes, from formulation to the filling step, which can improve AI for the aroma attribute.

Flavor perception can be directly related to social and geographical characteristics of the participants. The amount of whey added to fruit juice appears as a determining and inconsistent variable in the acceptance or rejection of beverages. Pareek et al. (2014) found negative acceptance for the attributes flavor, sweetness, and appearance due to higher whey levels. Shiby et al. (2013) reported opposite results, and concluded that the higher the concentration of whey, the better the acceptance of such beverages.

For the attributes color, sweetness, and acidity, the results showed that these three characteristics were close to ideal (score 5), with a slight tendency for acidity to be classified as "very low in relation to the ideal" (Figure 5), probably due to consumers' expectation about the acidity of orange juice.

Greater $(p<0.05)$ purchase intention was observed among female consumers, with mean scores close to 1 (probably buy). Regarding aroma, higher scores were obtained by the participants up to 20 years old when compared to older participants (over 20 years old). Physical activity did not influence the preferences for all the attributes (Table 2). These data indicate that the beverage can be directed to young people and women, regardless of physical activity.

Estimating industrial production costs comprises complex calculations, requiring variables that were not measured or are beyond the scope of this paper, such as 
Table 2 - Median (Med), mean and standard deviation $(\bar{x} \pm \sigma)$ of sensory evaluation scores for overall impression (0.I.), aroma (Ar), flavor (Flv), color (Clr), sweetness (Swt), acidity (Ac) and purchase intention (P.I.) of micro-filtered beverage made from whey and orange juice performed with 87 participants grouped according to gender, physical activity frequency and age.

\begin{tabular}{|c|c|c|c|c|c|c|c|c|}
\hline & & \multicolumn{2}{|c|}{ Gender } & \multicolumn{2}{|c|}{ Physical Activity } & \multicolumn{2}{|c|}{ Age } & \multirow{2}{*}{$\begin{array}{c}\text { Total } \\
\mathrm{n}=87\end{array}$} \\
\hline & & $\begin{array}{c}\text { Male } \\
\left(n^{*}=37\right)\end{array}$ & $\begin{array}{c}\text { Fem } \\
(n=50)\end{array}$ & $\begin{array}{c}\text { No } \\
(n=42)\end{array}$ & $\begin{array}{c}\text { Yes } \\
(n=45)\end{array}$ & $\begin{array}{c}\leq 20 \\
(n=45)\end{array}$ & $\begin{array}{c}>20 \\
(n=42)\end{array}$ & \\
\hline \multirow{2}{*}{ 0.1. } & Med & $6.00 \mathrm{a}$ & $6.00 \mathrm{a}$ & $6.00 \mathrm{a}$ & $6.00 \mathrm{a}$ & $6.00 \mathrm{a}$ & $6.00 \mathrm{a}$ & 6.00 \\
\hline & $\bar{x} \pm \sigma$ & $6.41 \pm 1.52$ & $6.28 \pm 1.16$ & $6.37 \pm 1.22$ & $6.30 \pm 1.42$ & $6.56 \pm 1.27$ & $6.10 \pm 1.34$ & $6.33 \pm 1.32$ \\
\hline \multirow{2}{*}{ Ar } & Med & $6.00 \mathrm{a}$ & $6.00 \mathrm{a}$ & $6.00 \mathrm{a}$ & $6.00 \mathrm{a}$ & $6.00 \mathrm{a}$ & $5.00 \mathrm{~b}$ & 6.00 \\
\hline & $\bar{x} \pm \sigma$ & $5.81 \pm 2.18$ & $5.70 \pm 1.92$ & $5.60 \pm 1.97$ & $5.89 \pm 2.09$ & $6.24 \pm 1.90$ & $5.21 \pm 2.04$ & $5.75 \pm 2.02$ \\
\hline \multirow{2}{*}{ Flv } & Med & $6.00 \mathrm{a}$ & $6.00 \mathrm{a}$ & $6.00 \mathrm{a}$ & $6.00 \mathrm{a}$ & $6.00 \mathrm{a}$ & $6.00 \mathrm{a}$ & 6.00 \\
\hline & $\bar{x} \pm \sigma$ & $5.86 \pm 1.86$ & $5.98 \pm 1.77$ & $5.91 \pm 1.67$ & $5.95 \pm 1.93$ & $6.02 \pm 1.90$ & $5.83 \pm 1.70$ & $5.93 \pm 1.80$ \\
\hline \multirow{2}{*}{$\mathrm{Clr}$} & Med & $5.00 \mathrm{a}$ & $5.00 \mathrm{a}$ & $5.00 \mathrm{a}$ & $5.00 \mathrm{a}$ & $5.00 \mathrm{a}$ & $5.00 \mathrm{a}$ & 5.00 \\
\hline & $\bar{x} \pm \sigma$ & $5.30 \pm 1.54$ & $4.64 \pm 1.54$ & $5.05 \pm 1.50$ & $4.80 \pm 1.64$ & $5.16 \pm 1.52$ & $4.67 \pm 1.59$ & $4.92 \pm 1.56$ \\
\hline \multirow{2}{*}{ Swt } & Med & $5.00 \mathrm{a}$ & $5.00 \mathrm{a}$ & $5.00 \mathrm{a}$ & $5.00 \mathrm{a}$ & $5.00 \mathrm{a}$ & $5.00 \mathrm{a}$ & 5.00 \\
\hline & $\bar{x} \pm \sigma$ & $5.19 \pm 1.58$ & $4.96 \pm 1.26$ & $4.93 \pm 1.26$ & $5.18 \pm 1.53$ & $5.09 \pm 1.47$ & $5.02 \pm 1.33$ & $5.06 \pm 1.40$ \\
\hline \multirow{2}{*}{$A c$} & Med & $5.00 \mathrm{a}$ & $5.00 \mathrm{a}$ & $5.00 \mathrm{a}$ & $5.00 \mathrm{a}$ & $5.00 \mathrm{a}$ & $5.00 \mathrm{a}$ & 5.00 \\
\hline & $\bar{x} \pm \sigma$ & $4.73 \pm 1.47$ & $5.10 \pm 1.16$ & $4.93 \pm 1.06$ & $4.95 \pm 1.52$ & $4.96 \pm 1.40$ & $4.93 \pm 1.22$ & $4.94 \pm 1.31$ \\
\hline \multirow{2}{*}{ P.I. } & Med & $3.00 \mathrm{a}$ & $3.00 \mathrm{~b}$ & $3.00 \mathrm{a}$ & $3.00 \mathrm{a}$ & $3.00 \mathrm{a}$ & $3.00 \mathrm{a}$ & 3.00 \\
\hline & $\bar{x} \pm \sigma$ & $3.22 \pm 0.98$ & $2.80 \pm 0.90$ & $2.91 \pm 0.92$ & $3.05 \pm 0.99$ & $2.87 \pm 0.94$ & $3.10 \pm 0.96$ & $2.98 \pm 0.95$ \\
\hline
\end{tabular}

abMedians followed by different lowercase letters in lines differ by the Mann-Whitney test $(p<0.05)$; *Number of participants.

transportation costs, labor force, electricity and many others. However, we can calculate the direct cost of the material used during the beverage development in this study. Thus, the direct material cost was US $\$ 0.38$ per $\mathrm{m}^{3}$ of feed (US\$ 0.25 for orange juice plus US\$ 0.13 for whey).

Given that the yield from the process in pilot scale was $55 \%$ (18.20 L feed was needed for every $10 \mathrm{~L}$ permeate), the final cost was US $\$ 0.69$ per $\mathrm{m}^{3}$ of permeate (no including water, direct labor and manufacturing overhead costs).

We emphasize that the beverage was developed in pilot equipment and in batches of only $20 \mathrm{~L}$, with a $16 \%$ average loss relative to the dead volume of the filtration unit. Therefore, cost estimation using experimental data is not recommended for prediction in industrial plants, where the results may be different especially in relation to yield and raw material costs, where the latter is directly dependent on the quantity acquired and delivery logistics.

\section{Conclusions}

Due to membrane fouling, beverage production was only possible when high transmembrane pressures were used. The whey/orange juice ratio was also decisive for the passage of the beverage through the membrane.

A clear beverage with lower viscosity, turbidity and protein levels was obtained by the microfiltration process, without altering the concentrations of naturally occurring minerals, showing thus that the product has good capacity for hydration.

The micro-filtered beverage presented good microbiological quality E.coli was not detected in the permeate, and the counts were low of aerobic mesophilic bac- teria, coliforms at $35^{\circ} \mathrm{C}$, molds and yeasts. Therefore, the beverage remained stable during 28 days of refrigerated storage, without increase in microbiological counts and physicochemical changes. Concerning the sensory evaluation, the overall acceptance was satisfactory and the product was preferred more often by young and female consumers. However, improvements are required in aroma and flavor.

It can be concluded that the beverage presented satisfactory results regarding the physicochemical and microbiological parameters, and good sensory acceptance, despite the limitation caused by membrane fouling. However, further studies are needed to assess the product shelf life after 28 days of refrigerated storage, to investigate other nutritional compounds and develop strategies to prevent fouling and reduce the particle retention desirable for beverage composition.

\section{Acknowledgements}

To Coordination for the Improvement of Higher Level Personnel (CAPES) and to National Foundation for the Development of Private Higher Education (FUNADESP) for financial support.

\section{References}

Agência Nacional de Vigilância Sanitária [ANVISA]. 2001. Technical regulation on microbiological standards for foods: resolution RDC no12, Jan 02, 2001 = Regulamento técnico sobre os padrões microbiológicos para alimentos: RDC $\mathrm{n}^{\circ} 12$, de 02 de janeiro de 2001. Available at: http://portal.anvisa. gov.br/documents/33880/2568070/RDC_12_2001.pdf/15ffddf63767-4527-bfac-740a0400829b [Accessed Mar 18, 2016] (in Portuguese). 
American Public Health Association [APHA]. 2004. Standard Methods for the Examination of Dairy Products. 16ed. American Public Health Association, Washington, DC, USA.

Antunes, A.E.C.; Alves, A.S.; Gallina, D.A.; Trento, F.K.H.S.; Zacarchenco, P.B.; Van Dender, A.G.F.; Spadoti, L.M. 2014. Development and shelf-life determination of pasteurized, micro-filtered, lactose hydrolyzed skim milk. Journal of Dairy Science 97: 5337-5344.

Brans, G.; Schroën, C.G.P.H.; Van der Sman, R.G.M.; Boom, R.M. 2004. Membrane fractionation of milk: state of the art and challenges. Journal of Membrane Science 243: 263-272.

Cisse, M.; Vaillant, F.; Perez, A.; Dornier, M.; Reynes, M. 2005. The quality of orange juice processed by coupling crossflow microfiltration and osmotic evaporation. International Journal of Food Science \& Technology 40: 105-116.

Domingues, R.C.C.; Ramos, A.A.; Cardoso, V.L.; Reis, M.H.M. 2014. Microfiltration of passion fruit juice using hollow fibre membranes and evaluation of fouling mechanisms. Journal of Food Engineering 121: 73-79.

Ferreira, V.L.P. 2000. Sensory Analysis: Discriminative and Affective Tests $=$ Análise Sensorial: Testes Discriminativos e Afetivos. Sociedade Brasileira de Ciência e Tecnologia de Alimentos, Campinas, SP, Brazil (in Portuguese).

Food and Agriculture Organization [FAO]. 2015. FAOSTAT emissions database: agriculture. Available at: http://faostat3. fao.org/download/Q/QC/E [Accessed Apr 26, 2016]

Gaschi, P.S.; Gaschi, P.S.; Barros, S.T.D.; Pereira, N.C. 2014. Pretreatment with ceramic membrane microfiltration in the clarification process of sugarcane juice by ultrafiltration. Acta Scientiarum Technology 36: 303-306.

Gerardo, M.L.; Oatley-Radcliffe, D.L.; Lovitt, R.W. 2013. Minimizing the energy requirement of dewatering Scenedesmus sp. by microfiltration: performance, costs, and feasibility. Environmental Science \& Technology 48: 845-853.

Lawless, H.T.; Heymann, H. 2010. Sensory Evaluation of Food: Principles and Practices. 2ed. Springer, New York, NY, USA.

Li, B.; Huang, M.; Fu, T.; Pan, L.; Yao, W.; Guo, L. 2012. Microfiltration process by inorganic membranes for clarification of Tongbi liquor. Molecules 17: 1319-1334.

Michalski, M.C.; Leconte, N.; Briard-Bion, V.; Fauquant, J.; Maubois, J.L.; Goudédranche, H. 2006. Microfiltration of raw whole milk to select fractions with different fat globule size distributions: process optimization and analysis. Journal of Dairy Science 89: 3778-3790.

Mourouzidis-Mourouzis, S.A.; Karabelas, A.J. 2006. Whey protein fouling of microfiltration ceramic membranes-Pressure effects. Journal of Membrane Science 282: 124-132.

Nourbakhsh, H.; Emam-Djomeh, Z.; Mirsaeedghazi, H.; Omid, M.; Moieni, S. 2014. Study of different fouling mechanisms during membrane clarification of red plum juice. International Journal of Food Science \& Technology 49: 58-64.

Oliveira, R.C.; Barros, S.T.D.; Gimenes, M.L.; Alvim, F.A.F.; Winter, C. 2010. Comparison between centrifugation and microfiltration on the clarification of passion fruit juice. Acta Scientiarum Technology 32: 271-278 (in Portuguese, with abstract in English).
Pareek, N.; Gupta, A.; Sengar, R. 2014. Preparation of healthy fruit based carbonated whey beverages using whey and orange juice. Asian Journal of Dairying \& Foods Research 33: 5-8.

Pegoretti, C.; Antunes, A.E.C.; Manchado-Gobatto, F.B.; Capitani, C.D. 2015. Milk: an alternative beverage for hydration? Food and Nutrition Sciences 6: 547-550.

Razi, B.; Aroujalian, A.; Fathizadeh, M. 2012. Modeling of fouling layer deposition in cross-flow microfiltration during tomato juice clarification. Food and Bioproducts Processing 90: 841-848.

Rezzadori, K.; Serpa, L.; Penha, F.M.; Petrus, R.R.; Petrus, J.C.C. 2014. Crossflow microfiltration of sugarcane juice: effects of processing conditions and juice quality. Food Science and Technology 34: 210217.

Rice, G.; Barber, A.; O'Connor, A.; Stevens, G.; Kentish, S. 2009. Fouling of NF membranes by dairy ultrafiltration permeates. Journal of Membrane Science 330: 117-126.

Shiby, V.K.; Radhakrishna, K.; Bawa, A.S. 2013. Development of wheyfruit-based energy drink mixes using D-optimal mixture design. International Journal of Food Science \& Technology 48: 742-748.

Solak, B.B.; Akın, N. 2012. Functionality of whey protein. International Journal of Health and Nutrition 3: 1-7.

Tan, T.J.; Wang, D.; Moraru, C.I. 2014. A physicochemical investigation of membrane fouling in cold microfiltration of skim milk. Journal of Dairy Science 97: 4759-4771.

Todisco, S.; Pena, L.; Drioli, E.; Tallarico, P. 1996. Analysis of the fouling mechanism in microfiltration of orange juice. Journal of Food Processing and Preservation 20: 453-466.

Tracey, E.M.; Davis, R.H. 1994. Protein fouling of track-etched polycarbonate microfiltration membranes. Journal of Colloid and Interface Science 167: 104-116.

Wang, K.; Zhou, C.; Hong, Y.; Zhang, X. 2012. A review of protein adsorption on bioceramics. Interface Focus 2: 259-277.

Watson, P.; Love, T.D.; Maughan, R.J.; Shirreffs, S.M. 2008. A comparison of the effects of milk and a carbohydrate-electrolyte drink on the restoration of fluid balance and exercise capacity in a hot, humid environment. European Journal of Applied Physiology 104: 633-642.

Wernimont, S.; Northington, R.; Kullen, M.J.; Yao, M.; Bettler, J. 2015. Effect of an $\alpha$-lactalbumin-enriched infant formula supplemented with oligofructose on fecal microbiota, stool characteristics, and hydration status a randomized, doubleblind, controlled trial. Clinical Pediatrics 54: 359-370.

Yadav, J.S.S.; Yan, S.; Pilli, S.; Kumar, L.; Tyagi, R.D.; Surampalli, R.Y. 2015. Cheese whey: a potential resource to transform into bioprotein, functional/nutritional proteins and bioactive peptides. Biotechnology Advances 33: 756-774. 